\title{
Web 2.0-enabled team relationships: an actor-network perspective
}

Article

Accepted Version

Soga, L. R., Vogel, B., Graca, A. and Osei-Frimpong, K. (2021) Web 2.0-enabled team relationships: an actor-network perspective. European Journal of Work and Organizational Psychology, 30 (5). pp. 639-652. ISSN 1464-0643 doi: https://doi.org/10.1080/1359432X.2020.1847183 Available at https://centaur.reading.ac.uk/93918/

It is advisable to refer to the publisher's version if you intend to cite from the work. See Guidance on citing.

Published version at: https://doi.org/10.1080/1359432X.2020.1847183

To link to this article DOI: http://dx.doi.org/10.1080/1359432X.2020.1847183

Publisher: Taylor \& Francis

All outputs in CentAUR are protected by Intellectual Property Rights law, including copyright law. Copyright and IPR is retained by the creators or other copyright holders. Terms and conditions for use of this material are defined in the End User Agreement.

\section{www.reading.ac.uk/centaur}

\section{CentAUR}

Central Archive at the University of Reading 
Reading's research outputs online 


\section{Web 2.0-enabled Team Relationships: An Actor-Network Perspective}

Lebene Richmond Soga ${ }^{a *}$, Bernd Vogel ${ }^{\mathrm{a}}$, Ana Margarida Graça ${ }^{\mathrm{a}}$, Kofi Osei-Frimpong $^{\mathrm{b}}$

${ }^{a}$ Henley Business School, University of Reading, Reading, UK.

${ }^{b}$ Faculty of Management Studies, University of Professional Studies, Accra, Ghana.

*Corresponding author details: lebene.soga@henley.ac.uk

This article is published in European Journal of Work and Organizational Psychology by Taylor \& Francis, 2020, available at https://doi.org/10.1080/1359432X.2020.1847183 


\title{
Web 2.0-enabled Team Relationships: An Actor-Network Perspective
}

\author{
Abstract \\ This paper examines how the deployment of Web 2.0 technologies, specifically \\ digital platforms for internal communication within organizations, influences the \\ nature of the team relationship. Previous research on the impact of these \\ technologies in teams call for new approaches and conceptualizations of \\ leadership. However, there is no consensus in the literature to help us understand \\ the nature of team relationships that are sustained by these technological \\ intermediations. To address this gap, we theoretically explore how the \\ intermediation of Web 2.0 technology within teams generates what we propose as \\ the technologized team relationship, in which the technology is as much a part of \\ the relationship as the humans involved. In doing so, we also highlight potential \\ unintended consequences for individuals in this technologized team relationship. \\ We underpin our analyses with Latourian actor-network theory, which recognizes \\ the agency of objects such as digital technologies in social relationships with \\ humans. We then propose a theoretical framework for understanding and \\ researching the nature of this technologized team relationship.
}

Keywords: Actor-network theory; Web 2.0 technologies; Team relationship; Unintended consequences. 


\section{Introduction}

The neologism - Web 2.0 - came from attempts in 2004 to underscore the changing nature of the Internet from a read-only, top-down technology to an increasingly participatory medium of exchange in which a user can co-create content as they interact with other users online (O'Reilly, 2007; Altamimi, 2013). Social technology platforms such as Yammer $^{\circledR}$, Huddle ${ }^{\mathrm{TM}}$, Google ${ }^{\circledR}{ }^{\circledR}$, Slack, Jive, among others exemplify this new conceptualization of the Web. It is predicted that the market for social technologies worldwide for organizations will grow by nearly a hundred per cent from approximately $\$ 2.7$ billion to $\$ 4.8$ billion by 2023 (Gartner, 2019). This group of technologies has become central influence in the last decade as organizations implement them to transform work relationships beyond established hierarchies (Coine \& Babbitt, 2014). Benefits of these technologies include enhancing the organization's internal practices of communication, collaboration on projects for virtual teams, idea sharing, and fostering team members' daily online interactions (Bughin et al., 2009).

Digital technology has the capability to drive change in how work is done (Grübler, 2003; Zuboff, 1996), shape outcomes in organizational practices (Tushman \& Murmann, 2003), increase flexibility in work processes (Lucas Jr \& Olson, 1994; Valcour \& Hunter, 2005), and challenge workforce competencies and individuals' identities (Turkle, 2005; Colbert, Yee, \& George, 2016). However, while Web 2.0 technologies as noted create various beneficial outcomes, we argue that the use of these technologies within organizations can also modify the nature and quality of team relationships among organizational members by enabling but also constraining the relationship (Adler, Kwon, \& Heckscher, 2008; Cascio \& Montealegre, 2016). 
Specifically, authors argue that social technologies reorganize how individuals relate in various social settings (Butts et al., 2015; Turkle, 2011), impact interpersonal relationships at work (Barley et al., 2011), and blur the boundary between work and non-work (Reyt \& Wiesenfeld, 2015). For teams, Larson and DeChurch (2020) for instance show that digital technologies can also actually be conceptualized as members of the team, not just the tools or the context within which teams operate.

In this paper, we aim to address what implications Web 2.0 technologies have for the relationship between a team leader and his/her team. We also theoretically examine what unintended consequences emerge for the relationship vis-à-vis this technological entrant. Here we define the team relationship that is formed and/or sustained through the intermediation of these Web 2.0 technologies as the technologized team relationship. The technology in this case is not only a mediator in the relationship but an intermediator (Bloomfield \& Vurdubakis, 2000). As a mediator, it is passive and just a medium or a tool for the relationship. As an intermediator, the technology is also a participant that influences, and is also influenced by the human actors in the relationship. To theorize the nature of this technologized team relationship, we draw on literature in organizational studies, leadership and teams (Avolio et al., 2000, 2014; Avolio \& Kahai, 2003; Cascio \& Montealegre, 2016; Gilson et al., 2015; Kipnis, 1993; Larson \& DeChurch, 2020) as well as sociotechnical literature (Akrich, 1992; Callon, 1986; Latour, 2005) to explore the phenomenon. We are inspired by sociotechnical literature in order to make the appropriate link to relational interactions with technology. Subsequently, we underpin our analyses with Latourian actor-network theory, which recognizes the obduracy of technical artefacts in a world in which the social setting is conceptualized as a heterogeneous assemblage of human and nonhuman (including technological) actors (Latour, 2005). 
By arguing a theoretical framework and raising propositions, this paper aims to make two main contributions. First, it contributes to the literature on virtual teams (Barry \& Fulmer, 2004; Cohen \& Gibson, 2003; Gibson et al., 2014; Larson \& DeChurch, 2020) by advancing a theoretical framework of the technologized team relationship for understanding Web 2.0 technological intermediation in teams. Second, through the utility of the actor-network theory, we make a methodological proposition that argues for the need to capture historical or real-time online interactions of teams in digital platforms for future research that explores this type of technologies in teamwork. To navigate this conceptual challenge, we structure this article as follows. We explore, first, various arguments about what Web 2.0 technologies mean for team relationships within organizations. Second, we discuss what unintended consequences emerge when these technologies become part of the team relationship. We then draw on Latourian ontology - actor-network theory (ANT) - to frame how the nature of team relationships formed by the implementation of these technologies are sustained and the methodological implications that are raised. Finally, we expand the methodological boundaries of the ANT approach in how the technologized team relationship can be researched.

\section{Web 2.0 Technology and Team Relationships}

The traditional view of Web 2.0 refers to applications that thrive on user content generation, e.g. wikis, blogs, RSS filters, folksonomies, mashups, podcasts, social networks, etc. (Andriole, 2010). With this underlying architecture also emerged several enterprise applications such as Slack, Huddle, Pharmacy Unscripted, Yammer, etc. in organizations that seek to foster internal social networks and collaborative teamworking among employees. These applications represent an integration of Web 2.0 technologies into contemporary organizations so that they could also be called Enterprise 2.0 
(McAfee, 2006). With their collaborative affordances, Web 2.0 technologies thus create 'virtual' environments for teams that are enabled and/or sustained by these enterprise applications. The virtual work environments are referred to as e-environments (Mohammad, 2009), participatory web cultures (Beer \& Burrows, 2010), transparent work environments (Meyer \& Kirby, 2010), digital environments (Bennis, 2013), or simply the Web 2.0 technology based environment. These environments challenge existing leadership relationships in ways that depart from established hierarchies (Barry \& Fulmer, 2004; Hoch \& Kozlowski, 2014). This is because the technological architecture of Web 2.0 as a participatory medium of exchange legitimizes new ways of conceptualizing how teams of humans interact among themselves at work (O'Reilly, 2007). Additionally, what the concept of team-work entails is now often elusive (Okhuysen et al., 2013), with the idea of team virtuality also lacking conceptual clarity (only recently reconceptualized as team perceived virtuality thus offering a nuanced theoretical clarity (see Handke et al., 2020)). The technologized team relationship can therefore be thought of as a social influence process having emergent properties that are formed, shaped, sustained or constrained by the technological intermediations and the human actors involved in the relationship.

Debates in the literature about technology's role and/or its impacts on team relationships show a broad range of perspectives (Barry \& Fulmer, 2004; Cohen \& Gibson, 2003; Gilson et al., 2015). Larson and DeChurch (2020) outline four perspectives with reference to digital technologies in teams: 1) Technology as team context, where the technology is what creates the conditions that affect teamwork; 2) Technology as sociomaterial team practices, where teamwork and technology are entangled in practice being mutually dependent on one another; 3) Technology as team creation medium, where technology is the enabler that actually determines the new 
forms of organizing among and/or within teams; 4) Technology as teammate, where technology is an active team player within the team.

These four perspectives also represent debates in sociotechnical literature and organization studies where research conceptualizes technology as shaping the structure within which individuals work (Woodward, 1965; Thompson, 1967) or in technological determinism where the human is portrayed as a cog in a slot machine only there to respond to the dictates of technology (Ellul, 1967; Hughes, 1998; Lawson, Lawson, Latsis, \& Martins, 2007; Smith \& Marx, 1994, 1998; Wyatt, 2008). The counter perspectives are that it is humans who shape technology to organize how they wish to work (MacKenzie \& Wajcman, 1999) and the social constructionist idea that technology is a reflection of how humans have organized themselves (Klein \& Kleinman, 2002; Pinch \& Bijker, 1989). Other scholars consider humans and technology as entangled in practice (Orlikowski \& Scott, 2008; Scott \& Orlikowski, 2014 ) in a constantly evolving network society where digital technologies permeate nearly every facet of how humans organize and relate with themselves (Castells, 2001). The implication for these various perspectives is that technologized team relationships can often be indeterminate and therefore a challenge for team leaders as well as team members. Larson and DeChurch (2020) for instance posit twelve implications for team leadership that the intermediation of digital technologies pose for teams. The underlying assumption is that digital technology in teams engenders relational consequences at both the individual and team levels.

Some conceptual papers posit how these technological applications provide team leaders with avenues through which they can transmit their influence (Avolio \& Kahai, 2003; Avolio, Sosik, et al., 2014), enable informal ways in which teams can communicate with their leaders without hierarchical limitations (Tredgold, 2014), or 
generate team perceived virtuality which is "a shared affective-cognitive emergent state that is characterized by team members' co-constructed and collectively-experienced (1) distance and (2) information deficits, thereby capturing the unrealized nature of the team as a collective system" (Handke et al., 2020, p. 3, Authors' emphasis). These conceptual works contribute to our understanding of the impact of Web 2.0 technologies on team leadership climate, but there remains a gap in how the nature of the relationship between team leaders and their respective teams can be understood. Gilson et al. (2015) echo similar shortcomings in their ten-year comprehensive review of empirical research on virtual teams.

Empirical studies show these technologies as fostering participative and consultative styles of leadership rather than directive approaches (Korzynski, 2013), enhancing knowledge sharing among team members for product innovation (Bughin et al., 2009), giving managers the opportunity to engage quickly with employees and adapt to changing business needs (Bennis, 2013), and allowing managers to leverage technology for establishing leadership among peers (Luo et al., 2015). Other findings provide counterarguments of how these technologies influence team relationships. One position argues that these technologies replace face-to-face human interactions, which also have advantages of spotting non-verbal cues (Turkle, 2011). A second position proposes that organizations risk relational crises and lack of access to talent when they fail to engage with these technologies (Kouzes \& Posner, 2007; Warner \& Sandberg, 2010). This position argues that it is because an emerging workforce - millennials who are born in the digital age knows no other way of relating. A third position suggests that technology becomes an intermediary in team relationships which might increase the relational gap, therefore distancing the team leader from the rest of the team (Shamir \& Ben-Ari, 1999; Turkle, 2011). Other authors present Web 2.0 technological era as a 
given, requiring that managers rise to the challenge and be proactive in driving organizational life (Bradley \& McDonald, 2011; Bennis, 2013; Coine \& Babbitt, 2014). Unlike the conceptual arguments that focus largely on team leadership climate, these empirical works contribute to our understanding of leader-team interactions but also fall short of how the nature of the technologized relationship can be understood.

We recognize that the introduction of technology, a non-human actor, into human team relationships generates more questions than answers about the nature of the relationship (Simanowski, 2016). Therefore, in theorizing the intermediation of Web 2.0 technologies within a team, we build on themes that explore the intended outcomes of Web 2.0 technological implementation in teamwork (O'Reilly, 2007). We underscore the analysis implicitly with the law of unintended consequences (Mansfield, 2010) which posits the propensity for human-designed systems, like technology in the social, to generate outcomes that were not originally intended. Web 2.0 technologies create high interconnectivity for dispersed individuals (Castells, 2001) but their deployment for teamwork, we argue, can generate unintended consequences for team relationships that are largely overlooked in theory. Here, we draw on studies or arguments at the overall level of conceptualization, example, e-leadership (Avolio et al., 2000; Avolio, Sosik, et al., 2014; Avolio \& Kahai, 2003; Bennis, 2013; Kahai, 2013; Meyer \& Kirby, 2010) and studies that examine technological inputs on work processes and relationships at the level of practice (Barley et al., 2011; Bloomfield \& Vurdubakis, 2000; Cascio \& Montealegre, 2016; Church et al., 2002; Fleming \& Waguespack, 2007; Lucas Jr \& Olson, 1994; Orlikowski \& Scott, 2008). We consider practice in this case as materially intermediated "arrays of human activity centrally organized around shared practical understanding" (Schatzki et al., 2001, p.11) which teamwork is essentially about. 


\section{How Web 2.0 Technologies Generate Unintended Consequences for Team Relationships}

Managers in organizations tend to focus on external uses of Web 2.0 technologies like engaging with customers via Twitter, Facebook, Instagram, LinkedIn etc. that they lose sight of the impact these social technologies bring to team relationships inside the organization (Chui et al., 2013). Industry reports about these social technologies tend to encourage organizational uptake (Bughin et al., 2009; Deiser \& Newton, 2013) but managers are left to grapple with their consequences on team relationships. Chang and Kane (2013) consider this managerial dilemma as a "damned if you do, and damned if you don't" situation. In order to navigate the dilemma and theorize within this specific domain for teams, we construct four major themes - social interaction, participation, transparency, and information sharing - from O'Reilly (2007) which are intended outcomes of the technologized team relationship. We choose these themes for two reasons. First, because of their direct impact on team relational dynamics, and second, they are generic enough (in contrast to O'Reilly's (2007) technical terminologies) to help us explore them in the literature. From its conceptualisation in 2004 till date, EBSCOHOST database gives us 33,102 academic articles published in English with Web 2.0 as search term. Many of these articles refer to O'Reilly (2007), the principal proponent and architect of the Web 2.0 neologism, whose paper has over 10,000 citations. Although the bibliometric indicators suggest exhaustive analyses on Web 2.0, our impression from the thousands of abstracts of articles published reveals a lack of attention to team relationships. In fact, Newman et al. (2016) detail a retrospective analysis of Web 2.0 over the past eleven years and make no mention of its role in team relationships. Accordingly, these four themes - social interaction, participation, information sharing, and transparency - serve as the primary 
contingencies engendered by Web 2.0 for teams upon which we make our theoretical arguments.

\section{Social Interaction in a Web 2.0-enabled Team Relationship}

Web 2.0 technologies enable increase in daily interaction within teams at lower costs (Bughin et al., 2009) and with the deployment of these technologies, teams and their leaders can form new relationships that extend beyond geographic and departmental boundaries. We observe a displacement of spaces from the physical to a virtual realm where possibilities of how many individuals a person can interact with remain infinite (Castells, 2010). Nonetheless, the team relationship now takes a new form as the domain of influence changes. This new context for team relationships is one in which leadership is exercised within and through a medium of technology for social interaction among all actors - team leaders and their teams. In their theoretical work, Avolio et al. (2000) conceptualize this phenomenon as e-leadership, that is, leadership transmitted through advanced information technologies. Further, Avolio and Kahai (2003) position the concept of e-leadership as a technological means for leaders to achieve ends that were before only possible in face-to-face situations. Here the technology is an enabling intermediary in the relationship making e-leadership appear as a tool in a leader's portfolio for doing leadership (Huxham \& Vangen, 2000, 2005). This conceptualisation differs from Avolio et al.'s (2000) earlier argument where eleadership is not just a tool for doing leadership in the face of digital technologies, but a structural mechanism within which a discursive relationship between leadership and technology is enacted, with technology influencing but is also influenced by all actors involved.

Consequently, e-leadership presents a duality in its conceptualisation of an emerging team relationship. First, e-leadership as a relational concept enabled or 
facilitated by technology (Avolio et al., 2000), which in this case is Web 2.0, and second, e-leadership as a technological means for achieving specific outcomes in the relationship that were before only possible in face-to-face situations (Avolio \& Kahai, 2003). In the former, social interaction occurs between a leader and team as they relate through the technology. However, the latter creates avenues for isolation if the technology fails, or if team leaders deploying these technologies become so dependent on it as a tool that they risk isolating themselves from those they are supposed to be interacting with (Turkle, 2011). For instance, Shamir and Ben-Ari (1999) conceptually refer to the idea of tele-leadership to depict a team leader using technology like a military leader involved in the reading and interpretation of electronic information and transmitting instructions to his/her followers on the battlefield. This notion, the authors argue, presents a form of distant leadership isolating the leader from followers without any social interaction. The implication is that, team relationships are potentially broken in organizations for which technology is the only means by which team leaders close relational gaps in their teams, especially in today's boundary-less organizations (Gajendran \& Joshi, 2012; Lojeski \& Reilly, 2010; Shamir, 1999).

The intermediary role of these social technologies in teams appears paradoxical and therefore difficult to measure its direct impact on team relationships (Kahai, 2013). Avolio et al. (2000) for instance propose leader-member exchange (LMX) theory (Graen \& Uhl-Bien, 1995) as a promising basis to ground and explore such phenomenon. However, LMX theory in the context of Web 2.0 technologies theoretically problematizes the affordances of the technology; here, it is not just leadermember dyads that are at play but member-member dyads, as well as multi-actor relations established with the wider Web 2.0 context including other teams and external stakeholders of the organization. The implication is that because participation is open to 
everyone, several dyadic relationships must be considered which is a limitation to LMX in this context. Uhl-Bien's (2006) theoretical position is that although an LMX approach may inform us about "LMX relationships (or MMX, which is LMX applied to a peer [or TMX, which is team-member exchange]), we learn little about other types of relationships that may occur in leadership interactions. Additionally, for our purposes here, we learn little about relational processes" (Uhl-Bien, 2006, p. 668). Thus, the technologized team relationship goes beyond LMX, it presents us with a paradox both in its conceptualisation and investigation. As a result, we propose the following:

Proposition 1: Web 2.0 technologies that are implemented to support team interactions within organizations are more likely to promote distant leadership than relational forms of leadership that enhance the quality of the team relationship.

\section{Participation in a Web 2.0-enabled Team Relationship}

A team leader may solicit team participation for some team activity if the situation requires it. In recent times where Web 2.0 communicative platforms are deployed, team members' participation in team activities appears amplified. Bradley and McDonald (2011) argue that in order for organizations to reap full benefits from their deployment of these technologies, active team participation is often a determinant of success, not a situational or "provide and pray" approach. Additionally, Avolio et al. (2014) point out that the participatory systems that are now common in Web 2.0 platforms allow all individuals the freedom to self-disclose and share details about their work and other aspects related to their personal lives with one another. This argument assumes full participation of every member in the technologized relationship. However, generational categories in teams that assume different levels of technological savviness challenge the assumption of full participation in the relationship. Taxonomically, 
Bingham and Conner (2010) categorize these generations using Pew Research's report; Generation Y - those born between 1981 and 1997 (also referred to as Millennials) and Generation $\mathrm{Z}$ - those born after 1997, with both $\mathrm{Y}$ and $\mathrm{Z}$ considered as technology savvy. This categorisation places those born before 1981 outside the technologized team relationship since they are not part of the digital natives (Stanton \& Stanton, 2013).

Empirical research has shown that in contemporary organizations, generational gap significantly influences team values and work relationships among individuals. It impacts individuals' loyalty to the organization (Smola \& Sutton, 2002), influences how individuals perceive leader behaviours (Arsenault, 2004), engenders conflicting expectations in work relationships (Ng et al., 2010), and requires diverse leadership models to cater for the different generations (Albion \& Gutke, 2010). An implication is that a Web 2.0 savvy generation can be managed with a particular leadership style, although this lacks cognisance of intra-generational individual differences (Kouzes \& Posner, 2007; Warner \& Sandberg, 2010). We argue that these generational categorisations only depict apriorisms and oversimplifications that make us lose sight of non-participation as an outcome of a technologized team relationship. In fact, a universal acceptance of this generational taxonomy is also lacking (Livingstone \& Bober, 2003; Stanton \& Stanton, 2013; Vodanovich et al., 2010).

For those teams who participate in a technologized relationship, their collective engagement can enhance the team relationship through promotion of transparency (Bennis, 2013), offer team leaders the ability to identify individuals in their teams with leadership capabilities (Bilgram et al., 2008), challenge team leaders to be more collaborative in their practices (Newcombe, 2009), while also changing leader positions from established hierarchies to more emergent roles that these technologies enable (D’Agostino \& Cone, 2007; Fleming \& Waguespack, 2007). However, Leonardi, 
Neeley, and Gerber (2012) observe that participation over these technologies also offers leaders the opportunity to force their interpretations of issues on followers. That is, leaders deploy the technology, not through interactive intersubjectivity with those they lead (Weick et al., 2005), but in a one-sided way to generate buy-ins for ideas they wish to transmit. Leaders with positional power, the authors argue, feel they can simply force their own interpretations on others using the technology as a medium, while those leaders without positional power only actively use the technology to enrol followers. Here, exclusion of individuals who for some reason do not engage with these technologies is overlooked. In other words, without participation, individuals would neither belong to the less-powerful group that are forced-in by leaders on issues, nor would they be those taking advantage of the shift in power towards them. This nonparticipation in a Web 2.0 technological platform therefore poses a challenge to team leaders who have deployed these technologies to enhance their relationships (Venters et al., 2012). Consequently, Web 2.0 technologies may enable participation within teams but exclusion of individuals, as an unintended consequence remains a challenge to grapple with. We propose the following:

Proposition 2: Team interactions over Web 2.0 technologies silences an excluded group of individuals resulting in an overestimation of power by those participating in the technologized team relationship.

\section{Information Sharing in a Web 2.0-enabled Team Relationship}

Information sharing is one way of empowering team members and eliciting suggestions (Chan, 2013). It allows the voice of individuals to be heard in the team. Individual voice in the team may occur as a breaking of silence (Milliken et al., 2003), a means through which members challenge certain team practices including leadership (Detert \& Burris, 2007), a way to relate with peers - speaking out - as well as with 
those in leadership positions - speaking up (Liu et al., 2010), or a product of confidence and trust in team leadership (Gao et al., 2011). Accordingly, Chan (2013) argues that leaders create more open channels of communication through which information can be shared to encourage voice activities. The author positions the study with a theoretical model of paternalistic leadership (Pellegrini \& Scandura, 2008), underpinned by the Confucian ideal of compliance and harmony (Westwood, 1997). Here we contend that information sharing in open communication channels can be hindered by information protection or (self-)censorship if that is what will ensure compliance and harmony. Randel and Ranft (2007) show that individuals' personal motivations may influence information sharing practices in team relationships. Moreover, information can be of a social nature - relating to individual relationships, aspirations, personal motivations and so on - or contextual - relating to the milieu surrounding tasks (Cramton \& Orvis, 2003). As a result, team members may withhold information if it does not fulfil their personal motivations or if it is deemed undesirable for their relational needs.

Here we argue that technologies like Web 2.0 platforms, can serve as a vehicle for sharing as well as withholding information in a team relationship (Mesmer-Magnus et al., 2011). This is a paradox, which Cramton and Orvis (2003) argue is a challenge to what they term technology-mediated communication. Howard (2006) for instance argues how through a process of political redlining, individuals share or withhold information from certain groups of people as a result of their online activities by using technologies like Web 2.0. This implies that in a team relationship that is only nurtured in a Web 2.0 environment, actors in the relationship may not know whether information is being withheld from them or otherwise. This is because the technology itself has a role to play in the distribution patterns of the information (Takaragawa \& Carty, 2012), which belies the idea of transparency in a Web 2.0 era. Akrich (1992) argues that 
technology possesses inscribed rules about how users of the technology should interact with it. These inscriptions are outcomes of the innovator's beliefs about how the technology and its user would (or rather must) relate under particular settings for which the technology is designed. Team members of a technologized team relationship may therefore be oblivious to these technological inscriptions.

Additionally, Kim and Lee (2006) show that individuals' usage of digital technologies within the organization influences their information sharing practices. From a survey of 322 individuals, the authors found that engagement with these technologies positively impacts their information sharing practices as long as they perceive the technology as having a high degree of ease of use. Implicitly, technologyenabled information sharing carries notions of information withholding as an unintended consequence when individuals perceive the technology as non-user-friendly. Here we argue that this does not preclude team members from engaging other means to share information, especially if that information satisfies their relational needs. We thus propose the following:

Proposition 3: Information sharing in a technologized team relationship is determined by the motivations of the one sharing the information, the nature of the information to be shared, and the perception held about the Web 2.0 technological platform on which the information is shared.

\section{Transparency in a Web 2.0-enabled Team Relationship}

The idea of transparency "involves not just [the] availability of information but active participation in acquiring, distributing and creating knowledge" (Cotterrell, 1999, p. 419). This implies all those with interest in the acquisition, distribution and creation of information in any given relationship must participate. For Bennis (2013), the onus for transparency shifts more towards the leader than the led. He argues that increasing 
transparency is a result of digitisation and leaders must recognize its power for their leader-follower relations. The author then highlights Onward: How Starbucks Fought for its Life Without Losing its Soul, a book by Howard Schultz (Starbucks CEO) in which he narrates receiving feedback and information from 17,000 coffee shops around the world. Bennis (2013) argues that this was possible because digital technology had enabled such capacity to get feedback so quickly and respond accordingly that Starbucks avoided reputational damage. However, the author discounts the potential for this technologically enabled transparency to become a tool for the leader to use against the led, e.g. surveillance. He states rather in passing, "transparency is inevitable at every stage of our existence. Yes, it will be misused, but we had better learn about it and embrace it if we are going to be effective leaders in the digital world" (Bennis, 2013, p. 636).

Jaradat (2013) interviews only leaders (consisting of deans, deputy deans, and heads of departments) about how they perceive the idea of transparency. The data obtained shows how these leaders endorse their own activities as being transparent: e.g. transparency is "access to information by university staff..."; "fighting all forms of corruption"; "applying open-door policy" and so on (Jaradat, 2013, p. 78). The implication is that, a leader's business-as-usual could pass as the ideal for transparency while other individuals are taken out of the picture. For a technologized team relationship, we argue that transparency is as much a concern for the leader as it is for the team member (Meyer \& Kirby, 2010; Norman et al., 2010). Florini (2007) argues that this age of transparency (Meyer \& Kirby, 2010) or the digital world (Bennis, 2013) does not necessarily make transparency inevitable, as Bennis (2013) rather asserts. Arguments regarding transparency are a bit more nuanced in the manufacturing industry in which technology that is installed to automate work processes simultaneously 
"informates" (Zuboff, 1988), that is it generates information about other work processes that it was not originally intended to do. While this opens up work processes, technology's "informating” power can equally be a tool for surveillance or control depending on the context under investigation. This is because, "some of the same technologies that have fostered the information revolution are being used to control the resulting flow of information" (Florini, 2007, p. 5). This control of the resulting flow of information forms part of the concept of surveillance in many organizations that have deployed technology as part of their teamwork (West \& Bowman, 2016). For the technologized relationship, surveillance becomes an unintended consequence that potentially compromises transparency in teamwork (Grimmelikhuijsen, 2012).

Moreover, surveillance is shown in theory to be detrimental for leadership in organizations. It breaks trust between leaders and followers (Westin, 1992), reduces individuals' perception of personal control thereby decreasing task performance and job satisfaction (Stanton \& Barnes-Farrell, 1996), and it militates against leaders' ability to influence when individuals get the impression that they are being monitored (Subašić et al., 2011). Nonetheless, Andrejevic's (2004) position on surveillance challenges the assumption that surveillance is only an instrument for leaders in work relationships. He argues that surveillance does not necessarily diffuse from a centralized location in a hierarchical fashion (such as from managers, or commercial entities, the State, etc.) but can also be lateral, that is, in a teamwork peer-to-peer situation. Other authors push this idea further with the concept of participatory surveillance or self-surveillance (Best, 2010; Lupton, 2013). That is, individuals turn the monitoring gaze on themselves for their own purposes. An example of self-surveillance is the use of self-tracking technologies or applications for self-management. These concerns are an indication of the blurring of the boundary between what is private and what is public, a dichotomous 
relationship created by communication technologies such as Web 2.0 applications (Livingstone, 2005). For team relationships, we add a fourth dimension of bottom-up surveillance where the leader is equally subject to monitoring in as much the same way as centralized diffusion of surveillance, lateral surveillance (or participatory), or selfsurveillance. As such, the nature of surveillance allowed in a Web 2.0-enabled team relationship simultaneously gives nuances to transparency in ways that are difficult to measure. We believe this creates opportunities for further investigation and theorizing. We thus propose the following:

Proposition 4: Transparency in a technologized team relationship is determined by the perception, nature and extent of surveillance in the team.

Insert Table 1 about here

\section{Framing with Latourian Ontology - The Actor-Network Theory}

The actor-network theory (ANT) outsteps traditionally held dichotomies of nature/societies thus positing the social as materially heterogeneous (Latour, 2005; Law, 1992). Here, both humans and non-humans - things, technology, texts, machines, etc. all constitute the social and therefore are actors (or actants) in the heterogeneous network of relations. The implication is that, technologically enabled social relationships, such as those nurtured on Web 2.0 digital platforms, are made up of humans and the very technologies sustaining those relationships (Latour, 2005). Example, instead of thinking of a virtual team as constituting the team leader and team members using technology, we would now consider it as comprising the team leader, team members and the very technologies that render them "virtual". In effect, a social relationship involving technology cannot be a relationship without the technology that 
also constitutes the relationship. This position challenges the nature of what counts as "social" but it is not without criticism (see Elder-Vass, 2015; Shapin, 1998). However, ANT's approach to sociology, which is also its "radical and controversial contribution" (van House, 2004, p. 15) is that, it helps us re-examine how we understand and research social relationships. For ANT theorists, a relationship must be understood as a set of entities brought together, of which the character is undetermined (Callon, 1993; Law, 2004). Its undetermined nature means that relationships are intermeshed with unidentifiable processes that call for constant negotiations from actors in the relationship. In order for actors to maintain their positions, they will have to reorder themselves in response to any shifts in the relationship.

In a technologized team relationship, established hierarchy is not readily visible. For example, on Web 2.0 platforms such as Google+, Huddle, Yammer, etc., a casual observer may not immediately see any hierarchical positions of individuals in that technologized relationship. Notwithstanding, the team members may choose to add their job titles to their names on the technological platform for self-assertion. They may also choose to add their job roles so that others can see who or what position they occupy in the hierarchy. However, the technology, which is also a participant in the relationship, may not allow this if the number of allowable characters for job titles or roles does not suffice. Moreover, team members in the relationship may take on certain tasks that do not match their job designations. For instance, an individual may become the team's Web 2.0 technological platform "conversations moderator", a task that is not necessarily what their job designation is. Thus, the relational processes among team members are constantly changing as they gain different ontological characters. Here, ANT suggests that actors become known by their relational responses to others in the relationship. Law (1992) argues that actors in the relationship are generated effects of a 
heterogeneous network of interacting materials that make up the relationship. Therefore, we posit that in order to sustain the technologized team relationship, actors in the relationship adopt strategies that reinforce their own intentions for being in the relationship; this in turn amplifies the unintended consequences, summarized in Table 1. This is because the actor is not one without the relationship that defines it (Law, 1992; Latour, 2005). In fact, ANT posits that we must "speak of actor-networks: for an actor is also a network" (Callon, 1991, p. 142, Author's emphasis).

This ANT argument underpins our conceptualisation of the Web 2.0-enabled team relationship as a technologized relationship, that is, not just a technologicallymediated-relationship. It enables us to see technology, both as describing and constituting the relationship. This implies that it is insufficient to research only the human actors without accounting for the non-human actants that also constitute the heterogeneous relationship. It is therefore a shift from individuals to assemblages of individuals and technology as the unit of analysis. As we have shown earlier, the technologized team relationship is one in which the relationship is indeterminate and therefore difficult to measure in quantifiable terms. From the ANT perspective, this relationship is one in which a positional team leader is now on equal terms with the rest of the team as well as the technology through which they are all linked together. Law (1992) for instance asserts Napoleons are no different in kind to commoners. For instance, on a Web 2.0 platform, a team leader is as much a "user" of the technology as is the rest of the team and no one is ontologically privileged.

Similarly, ANT theorist Callon (1986) establishes the notion of generalized symmetry, which implies that, the same descriptive or explanatory framework that is employed for team leaders in the relationship must also be used for both team members and the technology. He also argues that it requires the researcher to be impartial to the 
voice of all actors in the relationship. Methodologically, this implies allowing both team leader and the team to speak for themselves in a qualitative undertaking or research strategy. He then posits that actors in the relationship must be allowed their selfdetermination in the relationship without the researcher imposing any pre-established grid of analysis. These ANT arguments imply an ethnomethodology of following teams in order to trace how their relationships are formed and sustained (Callon, 1986; Latour, 2005; Nimmo, 2011). Here, the researcher also pays equal attention to the technology in order to understand the nature of the relationship.

The methodological implications of ANT are not without weakness, which is a result of its ontological assertions, thus making the "ANT method" sometimes difficult to operationalize. Example, ANT does not make clear from where we begin tracing actors in a network of relations since the network is unbounded (Latour, 2005). We have assumed "following teams" to trace the relationship, but it may as well be that we must follow the technology instead and therefore that becomes a pragmatic decision for the researcher. ANT is also criticized as being only descriptive with no explanatory power so that in tracing actors in a leadership relationship, we are left with describing the context of that relationship without explaining why it is so. Callon (1991) for instance argues that "to describe a skill is thus, at the same time, to describe its context" (Callon, 1991, p. 138) and therefore we might need some leadership theory to support the analysis. The idea of generalized symmetry also presents us with not only an ontological challenge as we grapple with technology's non-human membership of the leadership relationship (Collins \& Yearley, 1992; Elam, 1999), but also an epistemological challenge as the researcher must give voice to the technology. Cresswell et al. (2010) acknowledge these weaknesses and suggest pragmatic approaches to navigating an ANT study since "methodology cannot resolve the higher 
epistemological [and ontological] debate[s]" (Cresswell et al., 2010, p. 9). Following, we explore the implications of this actor-network approach for the arguments raised so far with implications for future research and theory.

\section{Discussion}

The four themes drawn out of the literature show how the intermediation of Web 2.0 technologies enhances social interaction within teams, increases team participation, improves information access for all team members, and promotes transparency in team processes. Simultaneously, we observe that isolation from the team, exclusion from team activities, information censorship (often self-censorship), and team surveillance emerge as unintended consequences for the technologized team relationship. This represents a technologically induced relational paradox (see Table 1) that can be either positive or negative for individuals in the team (Marshall, 2006), and for distributed virtual working arrangements in particular (Leonardi, Treem, \& Jackson, 2010). In other words, the technology facilitates but also constrains the team relationship so that how we approach this relationship depends on the outcomes that the theoretical lens of the researcher affords. For ANT, the call for generalized symmetry (Callon, 1986) means that the researcher can potentially uncover both sides of the paradox since the Web 2.0 technology is also important in the analysis.

To explain this technologically induced relational paradox, Kipnis (1993) shows it is as much a philosophical as it is an empirical undertaking. Philosophically, Bimber (1994) argues three kinds of technology's impacts on human sociality (though grounded in technological determinism): the normative, nomological, and unintended consequences accounts. The normative is a decoupling of technology from ethical and political debates thus allowing it to be autonomous. The nomological is the argument that there is only one possible cause of social change, which is technology. The third 
account is the argument that the impact of technology on social phenomena often has consequences which social actors cannot anticipate (Mansfield, 2010). This third account is what is reflected in Kipnis' (1993) study in which he argues that technology provides opportunities for shaping people's behaviour by changing how users respond to the technology. These behaviour technologies as he calls them, offer systematic techniques for influencing individuals in the organization parallel to how leadership theories share "the idea that Person A causes Person B to do something that B would ordinarily not do" (p.149) only this time Person A is replaced by the technology. Nonetheless, it is worth noting that leadership theories have now gone beyond this conceptualisation of leadership as a sheer tool for influence even though such arguments still remain (Spector, 2014). Kipnis (1993) argues that the technology does not only influence subject behaviour, it also reflexively acts on the one using the technology to influence others thus affording it a metamorphic effect. The technology thus possesses embedded "inscriptions" (Akrich, 1992) that act on all users. Technological inscriptions are designed into the technology by its innovator in order to trigger and perpetuate a predetermined or pre-imagined relationship with users of the technology (Akrich, 1992). Example, a strange looking avatar is usually imposed on an individual who refuses to upload their own profile photo onto a Web 2.0 platform. Here, the technology possesses a built-in inscription to force the user to upload an appropriate image to represent who they are.

From actor-network theoretical perspective, our theorizing of the technologically induced relational paradox therefore means that the technology exercises agency on human actors in the relationship. In our view, which is also based on ANT, agency is the ability to act and elicit a response either with inherent intentionality in the case of a human agent, or (un)programmed intentionality in the case of a designed artefact. This 
raises two arguments for the nature of the technologized team relationship. First, if the manner in which the Web 2.0 technology is scripted does not reflect the team leader's or the team's relational needs, the relationship will be challenging to all parties in the relationship (Akrich, 1992; Akrich \& Latour, 1992). The team will have to negotiate a new usage - that is, a re-negotiated technological inscription - that reflects their relational needs (Figure 1). Example, if a team leader wishes to delete an inappropriate image posted by a team member on the team's Web 2.0 platform but the platform is not scripted to support this relational need, the leader has a number of options: comment on the inappropriateness of the image or parts of the image that was posted, annotate the image if the technology is scripted for that, ask the technology's innovator to re-script the technology to allow annotation or deletion of images, ask to review all images before they are posted onto the technological platform, or ask team members to stop sharing images altogether, and so on. Either option is a renegotiation of the usage of the technology in a way that may not fully satisfy the relational need of the team leader.

As argued earlier, ANT allows individuals to negotiate their positioning in the technologized team relationship in order to sustain their own intentions for being in the relationship (Brown et al., 2001), which in turn reinforces the unintended consequences. We argue that these relational responses by individuals in the relationship are not without the involvement of the technology. As a result, any other team member or team leader in the technologized relationship can use the technology to relationally respond to others in a way that either changes or maintains their own positioning in the team (Cunliffe \& Eriksen, 2011). Following the last example, a team member can still decide to post images on the technological platform if they believe it is a useful resource for the team, although the team leader might still not be able to delete images on the platform. 
A second argument for the character of the technologized team relationship is what we would refer to as relational power (Latour, 1986; Law, 1986; Leonardi et al., 2012). Here, hierarchical position of some team members and/or their technological knowhow, may influence the quality of team interactions. Although the architecture of Web 2.0 technologies does not promote hierarchical power, technologized team relationships are often set within organizations that have established hierarchies (Coine \& Babbitt, 2014; Tett, 2015). As a result, hierarchical power in the technologized relationship can skew relational power in the direction of the one who wields it (Leonardi et al., 2012). However, the technology continues to exercise agency in the relationship in that it is as much a part of the relationship as the rest of the team, therefore relational power may shift to the actor who knows how best to use the technology (Bilgram et al., 2008). In an empirical study of a large corporate, Oliveira and Clegg (2015) for instance show how technologies deployed to enhance accounting processes simultaneously redistributed relational power through socio-technical relations (what we call the technologized relationship) rather than just social relations; the technology is able to generate "“"power over" effects by redistributing relational power" (Oliveira \& Clegg, 2015, p. 445).

Furthermore, the perception of ease of use of the technology (Luo et al., 2015) can be an outcome of an individual's technological knowhow. As we have argued earlier, those with the technological knowhow are thus able to participate in the technologized relationship while other team members potentially become excluded. From actor-network theory's perspective that Napoleons are no different in kind to commoners (Law, 1992), even the team leader in this case can lose their relational power if they do not possess the technological knowhow. In other words, individuals may assume new roles in the team as a result of their technological know-how. This is 
because actors in the technologized relationship "gain their ontological character through the position they occupy within the shifting relationship" (Brown et al., 2001, p. 129).

Insert Figure 1 about here

Through the utility of the actor-network theory, our framing of the nature of the technologized team relationship is that the relationship holds in tension the team's relational needs as well as any hierarchical power or privileged position that actors in the relationship may have (Figure 1). Through technological inscriptions and/or individuals' technological knowhow, these factors are renegotiated so that they deliver the team's intended outcomes and/or produce unintended consequences. To sustain the technologized relationship, the team leader and the team renegotiate the technological inscriptions and/or their own relational power, for any given teamwork.

The argument that team leaders with hierarchical advantage may engage the technology to force their interpretation on the team (Leonardi et al., 2012) or cause "Person B to do something that B would ordinarily not do" (Kipnis, 1993, p. 149) reveals at least two underlying assumptions. First, that the technology is only serving a top-down purpose in the relationship without the converse holding true. Second, that all actors in a technologized team relationship maintain any existing power gaps, which remain static. We contend that these assumptions are untenable. This is because Web 2.0 technological platforms essentially jettison top-down engagement of users and no one group is privileged. Accordingly, any managerial power brought into the relationship is subject to negotiation as relational power. Because the technology is active in the relationship, possessing agency and able to elicit a behavioural response 
(Kipnis, 1993), or generate new structures (Avolio et al., 2000), or direct a pattern of usage with its inherent (re-negotiated) inscriptions (Akrich, 1992), we maintain that the technologized team relationship is heterogeneous, involving the technology, the team leader and the rest of the team all relationally responding to one another.

Methodologically, research needs to consider how the Web 2.0 technology which is part of the technologized team relationship was originally "pre-scripted" to be used, as well as how the technology is actually deployed in practice in order to understand any renegotiated technological inscriptions. In other words, research should compare "the world inscribed in the object and the world described by its displacement" (Akrich, 1992, p. 209). In practice, the ethnomethodological approach of following actors would now also include examining the technology's user manual and possibly interviewing the technology's designers for an opportunity to understand the world "inscribed" in the technology. Avolio et al. (2000) provide a methodological proposition when they theorized e-leadership. The authors argue that research in this field must examine the dialectic interplay between the structures enabled by leadership and those arising from the deployment of technology. Using Adaptive Structuration Theory as a lens (DeSanctis \& Poole, 1994), they show the need to take account of the relational needs and the corresponding interactions among individuals in the technologized relationship. Accordingly, the level of analysis is not individuals per se, but the resultant interactions engendered as a result of the technological intermediation. The authors then propose an experimental methodological design by which such interaction among actors might be measured.

However, the adaptive structuration theory they advance, though highlights a recursive relationship between technology and individuals, tends to be concerned with only emergent structures generated as a result of the interaction with technology. These 
structures are conceptualized as rules, resources (political and economic), and organizational culture (DeSanctis \& Poole, 1994; Klein \& Kleinman, 2002). The theory does not fully explain the more detailed actor-to-actor interactions in the technologized relationship. The implication is that it neglects in the analysis how the technology, as well as individuals came to organize and sustain the relationship. Additionally, it does not fully account for new relational practices that may emerge from the technologized relationship at the level of the individual actor. To capture the "micro" relational team interactions on a Web 2.0 platform, ANT's ethnomethodological approach needs to also capture netnographic information (Kozinets, 2010) from the Web 2.0 platform. In netnography, the research field is the technological platform through which the team relationship is sustained. It is essentially an ethnography of the team's practices in the online space, which is the field behind the screen (Kozinets, 2002). Accordingly, the researcher can capture either historical or real-time interactions between a team leader and the team on a technological platform as data in order to understand any renegotiated technological inscriptions and therefore the nature of the technologized team relationship. The historical data can also be used to ascertain how the technologized relationship has developed over time horizons while comparing the analysis with potential changes in team goals along the period under investigation. The main value of these approaches to deploying ANT in studies of this nature "lies in a more sophisticated appreciation of the fluid and multiple nature of reality, the view of the active role of objects in shaping social relationships, and a theoretically informed approach to guiding sampling and data collection” (Cresswell et al., 2010, p. 8).

\section{Future Research}

We have argued that ANT's principles enable the researcher to ethnomethodologically trace actor trajectories within the team without discounting the 
technologies in the relationship. The unit of analysis in this undertaking is the network of heterogeneous relations. Here we have argued that the relational processes among team members in the technologized relationship constantly change as they gain different ontological characters in the relationship. In order to sustain the relationship, individuals in the team would have to shift relationally in response to others in the relationship. To capture these micro level interactions, the ANT approach may be limited. Following, we propose that adding netnographic analysis will enable the researcher to capture the micro-level interactions as data for research into teams on Web 2.0 platforms. This is particularly important because the discursive practices of technologized teams in Web 2.0 platforms may provide insight into the team that qualitative interviews or observations may fail to capture. Example, Belz and Baumbach (2010) use netnography to identify lead users - a marketing term used to describe a rare and difficult-to-detect set of individuals who are ahead of market trends - in an online community. Research participants in netnography are "digital selves" - that is, digital or textual footprints left by those who have participated in an online space. In our view, the performativity of these digital footprints blurs the boundary of non-human vs human agency thus overcoming some of the criticisms of ANT's ontological assertions highlighted earlier.

Furthermore, the degree of virtuality that is present in a team could also influence how relational power plays out. Whereas some teams may be fully virtual, others may have more hybrid forms of engagement in both the virtual and face-to-face interactions. A longitudinal study involving comparative ethnography and netnography in different teams within the same firm might throw some light on how relational power is negotiated in such teams. The arguments raised in this paper become more nuanced in self-managed teams in which there is no clear designation of an individual as the leader. This provides an avenue for future research, that is, in exploring what the implications 
of technologized team relationships are for "leaderless" teams or how leadership becomes "emergent" in these teams (see Kozlowski et al., 2016).

Whereas organizations continue to grapple with the ramifications of Web 2.0 technologies with its multiple gaps in the literature, there are already computer systems that go beyond this Web 2.0 tag. Artificial intelligence systems, autonomous devices, augmented and mixed reality, 3D graphics, human agent collectives (HAC), Internet of things, and the idea of the semantic Web which all characterise what is now called Web 3.0 present even more complex challenges for teams (Kreps \& Kimppa, 2015; Rudman \& Bruwer, 2016). These technological advancements pose challenges for teams regarding control and potentially new team roles as a result of computer systems autonomy (Jennings et al., 2014). Future research could examine how these systems play their roles as new members of teams and what implications arise for the human actors involved. Professional service robots for instance appear in either human-likeness or machine-likeness as they work together with human counterparts in service delivery (Hinds et al., 2004) but their impact on team processes continue to remain unclear (Jung et al., 2017). Future research is thus needed to address these aspects, which our Web 2.0 focus is unable to speak to.

\section{Conclusion}

We have advanced in this paper the dynamics in team relationships that Web 2.0 technologies engender in contemporary organizations. These technologies enable a new kind of team relationship that is technologized. The technologized relationship assumes that technology is as much an actor in the relationship as the team leader and other members of the team. But with a new technological entrant in the relationship, unintended consequences emerge. First, we observe a case of technologically induced relational paradox in which team interaction in the technologized relationship 
potentially creates isolation while participation can also create an environment for exclusion. Here, we identify that generational gap within an organization is not necessarily a cause for exclusion in the technologized team relationship. Second, participation in the relationship provides the opportunity for a shift in relational power dynamics. Third, information (self-)censorship in a technologized team relationship can remain unnoticed as an unintended consequence of the Web 2.0 information-sharing era. Fourth, transparency in a technologized team relationship coexists with some degree of surveillance, the perception, nature and extent of the latter determines the former.

Our main contributions are twofold. First, we advance a theoretical framework for understanding the nature of the technologized team relationship, summarized in Figure 1. Through the underpinning theoretical lens of the actor-network theory, we argue that in technologized team relationships, relational power and technological inscriptions characterize the relationship but are renegotiated for any given teamwork in order to sustain the relationship. The technologized team relationship is an elusive one and holds in tension factors that allow it to deliver outcomes that may be intended or unintended in some cases. Second, we make a methodological contribution by pushing the boundary of ANT's ethnomethodological approach. Here we argue for the need to capture historical or real-time online interactions of technologized teams through netnography. We have also advanced four propositions, summarized in Table 1, and also identified other areas for future research. Finally, we believe that the utility of the actor-network theory in embracing technology as also possessing agency allows us to challenge assumptions of what team relationships entail, thus opening up avenues for future research and theorizing. This is because "attempts to "apply" an existing analytical perspective to a new object reveal (perhaps more clearly than is evident..) 
basic, taken-for-granted assumptions about the character and status of that [object]" (Woolgar, 1991, p. 20). 


\section{References}

Adler, P. S., Kwon, S.-W., \& Heckscher, C. (2008). Professional Work: The Emergence of Collaborative Community. Organization Science, 19(2), 359-376. https://doi.org/10.1287/orsc.1070.0293

Akrich, M. (1992). The Description of Technical Objects. In W. E. Bijker \& J. Law (Eds.), Shaping Technology / Building Society: Studies in Sociotechnological Change (pp. 205-224). MIT Press.

Akrich, M., \& Latour, B. (1992). A Convenient Vocabulary for the Semiotics of Human and Nonhuman Actors. In W. Bijker \& J. Law (Eds.), Shaping Technology / Building Society Studies in Sociotechnological Change. MIT Press.

Albion, P., \& Gutke, H. J. (2010, July 26). Successful succession through shared leadership: Preparing a new generation of educational leaders. Sydney Symposium The Future of Teacher Education and School Leader Education. Creating the Vision, Sydney, Australia.

Altamimi, L. (2013). A Lexical Analysis of Social Software Literature. Informatica Economica, 17(1), 14-26. https://doi.org/10.12948/issn14531305/17.1.2013.02

Andrejevic, M. (2004). The Work of Watching One Another: Lateral Surveillance, Risk, and Governance. Surveillance and Society, 2(4), 479-497. http://dx.doi.org/10.24908/ss.v2i4.3359

Andriole, S. J. (2010). Business impact of Web 2.0 technologies. Communications of the ACM, 53(12), 67-79. https://doi.org/10.1145/1859204.1859225

Arsenault, P. M. (2004). Validating generational differences: A legitimate diversity and leadership issue. Leadership and Organization Development Journal, 25(2), 124-141. https://doi.org/10.1108/01437730410521813 
Avolio, B. J., \& Kahai, S. S. (2003). Adding the 'E' to E-leadership: How it may impact your leadership. Organizational Dynamics, 31(4), 325-338. https://doi.org/10.1016/S0090-2616(02)00133-X

Avolio, B. J., Kahai, S. S., \& Dodge, G. E. (2000). E-Leadership: Implications For Theory, Research, And Practice. Leadership Quarterly, 11(4), 615-668. https://doi.org/10.1016/S1048-9843(00)00062-X

Avolio, B. J., Sosik, J. J., Kahai, S. S., \& Baker, B. (2014). E-leadership: Re-examining transformations in leadership source and transmission. The Leadership Quarterly, 25(1), 101-131. https://doi.org/10.1016/j.leaqua.2013.11.003

Barley, S. R., Meyerson, D. E., \& Grodal, S. (2011). E-mail as a Source and Symbol of Stress. Organization Science, 22(4), 887-906. https://doi.org/10.1287/orsc.1100.0573

Barry, B., \& Fulmer, I. S. (2004). The Medium and the Message: The Adaptive Use of Communication Media in Dyadic Influence. The Academy of Management Review, 29(2), 272-292. https://doi.org/10.2307/20159033

Beer, D., \& Burrows, R. (2010). Consumption, Prosumption and Participatory Web Cultures An introduction. Journal of Consumer Culture, 10(1), 3-12. http://dx.doi.org/10.1177/1469540509354009

Belz, F.-M., \& Baumbach, W. (2010). Netnography as a Method of Lead User Identification. Creativity and Innovation Management, 19(3), 304-313. https://doi.org/10.1111/j.1467-8691.2010.00571.x

Bennis, W. (2013). Leadership In A Digital World: Embracing Transparency And Adaptive Capacity. MIS Quarterly, 37(2), 635-636. 
Best, K. (2010). Living in the Control Society: Surveillance, Users and Digital Screen Technologies. International Journal of Cultural Studies, 13(1), 5-24. https://doi.org/10.1177/1367877909348536

Bilgram, V., Brem, A., \& Voigt, K. (2008). User-Centric Innovations In New Product Development-Systematic Identification Of Lead Users Harnessing Interactive And Collaborative Online Tools. International Journal Of Innovation Management, 12(3), 419-458. https://doi.org/10.1142/S1363919608002096

Bimber, B. (1994). Three Faces of Technological Determinism. In M. R. Smith \& L. Marx (Eds.), Does Technology Drive History? The Dilemma of Technological Determinism (pp. 79-100). MIT Press.

Bingham, T., \& Conner, M. (2010). The New Social Learning: A Guide to Transforming Organizations Through Social Media. Berrett-Koehler Publishers Inc.

Bloomfield, B. P., \& Vurdubakis, T. (2000). Paper Traces: Inscribing Organizations and Information Technology. In B. P. Bloomfield, R. Coombs, D. Knights, \& D. Littler (Eds.), Information Technology and Organizations: Strategies, Networks, and Integration (pp. 85-111). Oxford University Press.

Bradley, A. J., \& McDonald, M. P. (2011). The Social Organization: How to Use Social Media to Tap the Collective Genius of Your Customers and Employees. Harvard Business Review Press.

Brown, S. D., Middleton, D., \& Lightfoot, G. (2001). Performing the Past in Electronic Archives: Interdependencies in the Discursive and Non-Discursive Ordering of Institutional Rememberings. Culture and Psychology, 7(2), 123-144. https://doi.org/10.1177/1354067X0172001 
Bughin, J., Chui, M., \& Miller, A. (2009). How companies are benefiting from Web 2.0: McKinsey Global Survey results | McKinsey \& Company. http://www.mckinsey.com/insights/business_technology/how_companies_are_b enefiting_from_web_20_mckinsey_global_survey_results

Butts, M. M., Becker, W. J., \& Boswell, W. R. (2015). Hot Buttons and Time Sinks: The Effects of Electronic Communication During Nonwork Time on Emotions and Work-Nonwork Conflict. Academy of Management Journal, 58(3), 763788. https://doi.org/10.5465/amj.2014.0170

Callon, M. (1986). Some Elements of a Sociology of Translation: Domestication of the Scallops and the Fishermen of St Brieuc Bay. In L. J (Ed.), Power, Action and Belief (pp. 196-233). Routledge.

Callon, M. (1991). Techno-Economic Networks and Irreversibility. In J. Law (Ed.), $A$ Sociology of Monsters: Essays on Power, Technology and Domination (pp. 132161). Routledge.

Callon, M. (1993). Variety and Irreversibility in Networks of Technique Conception and Adoption. In D. Foray \& Freeman (Eds.), Technology and the Wealth of Nations: Dynamics of Constructed Advantage (pp. 232-268). Pinter.

Cascio, W. F., \& Montealegre, R. (2016). How Technology Is Changing Work and Organizations. In F. P. Morgeson (Ed.), Annual Review of Organizational Psychology and Organizational Behavior, Vol 3 (Vol. 3, pp. 349-375). Annual Reviews.

Castells, M. (2001). The Internet Galaxy: Reflections on the Internet, Business, and Society. Oxford University Press.

Castells, Manuel. (2010). The Rise of the Network Society: The Information Age: Economy, Society, and Culture (2nd ed., Vol. 1). Wiley-Blackwell. 
Chan, S. C. H. (2013). Paternalistic Leadership and Employee Voice: Does Information Sharing Matter? Human Relations, 0(0), 1-27. https://doi.org/10.1177/0018726713503022

Chang, K. K., \& Kane, G. C. (2013). Walking the Legal Tightrope of Social Business. MIT Sloan Management Review. http://sloanreview.mit.edu/article/walking-thelegal-tightrope-of-social-business/

Chui, M., Dewhurst, M., \& Pollak, L. (2013). Building the Social Enterprise (McKinsey Quarterly, November Ed.). McKinsey. http://www.mckinsey.com/insights/organization/building_the_social_enterprise

Church, A. H., Gilbert, M., Oliver, D. H., Paquet, K., \& Surface, C. (2002). The Role of Technology In Organization Development and Change. Advances in Developing Human Resources, 4(4), 493-511. https://doi.org/10.1177/152342202237525

Cohen, S. G., \& Gibson, C. B. (Eds.). (2003). Virtual Teams That Work: Creating Conditions for Effective Virtual Teams. Jossey-Bass Inc., Publishers.

Coine, T., \& Babbitt, M. (2014). A World Gone Social: How Companies Must Adapt to Survive. AMACOM.

Colbert, A., Yee, N., \& George, G. (2016). The Digital Workforce and the Workplace of the Future. Academy of Management Journal, 59(3), 731-739. https://doi.org/10.5465/amj.2016.4003

Collins, H. M., \& Yearley, S. (1992). Epistemological Chicken. In A. Pickering (Ed.), Science as Practice and Culture (pp. 301-326). Chicago University Press.

Cotterrell, R. (1999). Transparency, mass media, ideology and community. Journal for Cultural Research, 3(4), 414-426. https://doi.org/10.1080/14797589909367176

Cramton, C. D., \& Orvis, K. L. (2003). Overcoming Barriers To Information Sharing In Virtual Teams, In Gibson, C, \& Cohen. In C. Gibson \& S. Cohen (Eds.), Virtual 
Teams That Work: Creating Conditions For Virtual Team Effectiveness (eBook Collection EBSCOhost). Jossey-Bass.

Cresswell, K. M., Worth, A., \& Sheikh, A. (2010). Actor-Network Theory and its role in understanding the implementation of information technology developments in healthcare. BMC Medical Informatics and Decision Making, 10(67), 1-11. EDSWSS. https://doi.org/10.1186/1472-6947-10-67

Cunliffe, A. L., \& Eriksen, M. (2011). Relational Leadership. Human Relations, 64(11), 1425-1449. https://doi.org/10.1177/0018726711418388

D’Agostino, D., \& Cone, E. (2007). Taking the Lead. CIO Insight, 80, 49-55.

Deiser, R., \& Newton, S. (2013). Six social-media skills every leader needs | McKinsey \& Company.

http://www.mckinsey.com/insights/high_tech_telecoms_internet/six_socialmedia_skills_every_leader_needs

DeSanctis, G., \& Poole, M. S. (1994). Capturing the complexity in advanced technology use: Adaptive Structuration Theory. Organization Science, 5(1), 121-147. https://doi.org/10.1287/orsc.5.2.121

Detert, J. R., \& Burris, E. R. (2007). Leadership behaviour and employee voice: Is the door really open? Academy of Management Journal, 50(4), 869-884. https://doi.org/10.5465/amj.2007.26279183

Elam, M. (1999). Living Dangerously with Bruno Latour in a Hybrid World. Theory, Culture and Society, 16(4), 1-24. https://doi.org/10.1177/02632769922050692

Elder-Vass, D. (2015). Disassembling Actor-network Theory. Philosophy of the Social Sciences, 45(1), 100-121. https://doi.org/10.1177/0048393114525858

Ellul, J. (1967). The Technological Society with an Introduction by Robert K. Merton (J. Wilkinson, Trans.). Vintage Books. 
Fleming, L., \& Waguespack, D. M. (2007). Brokerage, Boundary Spanning, and Leadership in Open Innovation Communities. Organization Science, 18(2), 165180. https://doi.org/10.1287/orsc. 1060.0242

Florini, A. (2007). The battle over transparency. In A. Florini (Ed.), The Right To Know: Transparency for an Open World (pp. 1-18). Columbia University Press.

Gajendran, R. S., \& Joshi, A. (2012). Innovation in globally distributed teams: The role of LMX, communication frequency, and member influence on team decisions. Journal of Applied Psychology, 97(6), 1252-1261. https://doi.org/10.1037/a0028958

Gao, L., Janssen, O., \& Shi, K. (2011). Leader trust and employee voice: The moderating role of empowering leader behaviors. Leadership Quarterly, 22(4), 787-798. https://doi.org/10.1016/j.leaqua.2011.05.015

Gartner, Inc. (2019). Gartner Says Worldwide Social Software and Collaboration Revenue to Nearly Double by 2023. Gartner. https://www.gartner.com/en/newsroom/press-releases/09-24-2019-gartner-saysworldwide-social-software-and-collaboration-revenue-to-nearly-double-by-2023

Gibson, C. B., Huang, L., Kirkman, B. L., \& Shapiro, D. L. (2014). Where global and virtual meet: The value of examining the intersection of these elements in twenty-first-century teams. Annual Review of Organizational Psychology and Organizational Behavior, 1, 217-244. https://doi.org/10.1146/annurevorgpsych-031413-091240

Gilson, L. L., Maynard, M. T., Jones Young, N. C., Vartiainen, M., \& Hakonen, M. (2015). Virtual Teams Research: 10 Years, 10 Themes, and 10 Opportunities. Journal of Management, 41(5), 1313-1337. https://doi.org/10.1177/0149206314559946 
Graen, G. B., \& Uhl-Bien, M. (1995). Relationship Based Approach to Leadership: Development of Leader Member-Exchange (LMX) Theory of Leadership Over 25 Years: Applying a Multi-Level Multi-Domain Perspective. Leadership Quarterly, 6(2), 219-247. https://doi.org/10.1016/1048-9843(95)90036-5

Grimmelikhuijsen, S. (2012). A good man but a bad wizard. About the limits and future of transparency of democratic governments. Information Polity: The International Journal Of Government \& Democracy In The Information Age, 17(3/4), 293-302. https://doi.org/10.3233/978-1-61499-244-8-83

Grübler, A. (2003). Technology and Global Change. Cambridge University Press.

Handke, L., Costa, P. L., Klonek, F. E., O’Neill, T. A., \& Parker, S. K. (2020). Team perceived virtuality: An emergent state perspective. European Journal of Work and Organizational Psychology, 1-15. https://doi.org/10.1080/1359432X.2020.1806921

Hinds, P. J., Roberts, T. L., \& Jones, H. (2004). Whose Job Is It Anyway? A Study of Human-Robot Interaction in a Collaborative Task. Human-Computer Interaction, 19(1-2), 151-181. https://doi.org/10.1080/07370024.2004.9667343

Howard, P. N. (2006). Communication, Society, and Politics: New Media Campaigns and the Managed Citizen. Cambridge University Press.

Hughes, T. P. (1998). Technological Momentum. In M. R. Smith \& L. Marx (Eds.), Does Technology Drive History? : The Dilemma of Technological Determinism (pp. 1-36). MIT Press.

Huxham, C., \& Vangen, S. (2000). Leadership in the shaping and implementation of collaboration agendas: How things happen in a (not quite) joined up world. Academy of Management Journal, 43(6), 1159-1175. https://doi.org/10.5465/1556343 
Huxham, C., \& Vangen, S. (2005). Managing to collaborate. Sage.

Jaradat, M. H. (2013). The Notion Of Administrative Transparency Among Academic Leaderships At Jordanian Universities. Education, 134(1), 74-81.

Jennings, N. R., MoreauL, L., Nicholson, D., Ramchurn, S., Roberts, S., Rodden, T., \& Rogers, A. (2014). Human-agent collectives. Communications of the ACM, 57(12), 80-88. https://doi.org/10.1145/2629559

Jung, M. F., Šabanović, S., Eyssel, F., \& Fraune, M. (2017). Robots in Groups and Teams | Companion of the 2017 ACM Conference on Computer Supported Cooperative Work and Social Computing. Companion of the 2017 ACM Conference on Computer Supported Cooperative Work and Social Computing, 401-407. https://doi.org/10.1145/3022198.3022659

Kahai, S. S. (2013). Leading in a digital age: What's different, issues raised, and what we know. In M. C. Bligh \& R. E. Riggio (Eds.), Exploring distance in leaderfollower relationships: When near is far and far is near (pp. 63-108). Routledge.

Kim, S., \& Lee, H. (2006). The Impact of Organizational Context and Information Technology on Employee Knowledge-Sharing Capabilities. Public Administration Review, 66(3), 370-385. https://doi.org/10.1111/j.1540$6210.2006 .00595 . x$

Kipnis, D. (1993). Unanticipated Consequences of Using Behavior Technology. The Leadership Quarterly, 4(2), 149-171. https://doi.org/10.1016/10489843(93)90009-I

Klein, H. K., \& Kleinman, D. L. (2002). The Social Construction of Technology: Structural Considerations. Science, Technology, and Human Values, 27(1), 2852. https://doi.org/10.1177/016224390202700102 
Korzynski, P. (2013). Online social networks and leadership: Implications of a new online working environment for leadership. International Journal of Manpower, 34(8), 975-994. https://doi.org/10.1108/IJM-07-2013-0173

Kouzes, J. M., \& Posner, B. Z. (2007). The Leadership Challenge (4th ed.). JosseyBass.

Kozinets, R. V. (2002). The Field Behind the Screen: Using Netnography for Marketing Research in Online Communities. Journal of Marketing Research, 39(1), 61-72. https://doi.org/10.1509/jmkr.39.1.61.18935

Kozinets, Robert V. (2010). Netnography: Doing Ethnographic Research Online. Sage Publications Ltd.

Kozlowski, S. W. J., Chao, G. T., Grand, J. A., Braun, M. T., \& Kuljanin, G. (2016). Capturing the multilevel dynamics of emergence: Computational modeling, simulation, and virtual experimentation. Organizational Psychology Review, 6(1), 3-33. https://doi.org/10.1177/2041386614547955

Kreps, D., \& Kimppa, K. (2015). Theorising Web 3.0: ICTs in a changing society. Information Technology \& People, 28(4), 726-741. Emerald Insight. https://doi.org/10.1108/ITP-09-2015-0223

Larson, L., \& DeChurch, L. A. (2020). Leading teams in the digital age: Four perspectives on technology and what they mean for leading teams. The Leadership Quarterly, 31(1), 101377. https://doi.org/10.1016/j.leaqua.2019.101377

Latour, B. (1986). The Powers of Association. In J. Law (Ed.), Power, action and belief: A new Sociology of Knowledge? (pp. 264-280). Routledge and Kegan Paul. 
Latour, B. (2005). Reassembling the Social: An Introduction to Actor-network Theory. Oxford University Press.

Law, J. (1986). On power and its tactics: A view from the sociology of science. The Sociological Review, 34(1), 1-38. https://doi.org/10.1111/j.1467954X.1986.tb02693.x

Law, J. (2004). After Method: Mess in Social Science Research. Routledge. Law, John. (1992). Notes on the theory of the actor-network: Ordering, strategy, and heterogeneity. Systems Practice, 5(4), 379-393. https://doi.org/10.1007/BF01059830

Lawson, C., Lawson, C., Latsis, J. S., \& Martins, N. M. O. (2007). Technology, technological determinism and the transformational model of technical activity. In Contributions to Social Ontology (pp. 32-49). Routledge.

Leonardi, P. M., Neeley, T. B., \& Gerber, E. M. (2012). How Managers Use Multiple Media: Discrepant Events, Power, and Timing in Redundant Communication. Organization Science, 23(1), 98-117. https://doi.org/10.1287/orsc.1110.0638

Leonardi, Paul M., Treem, J. W., \& Jackson, M. H. (2010). The Connectivity Paradox: Using Technology to Both Decrease and Increase Perceptions of Distance in Distributed Work Arrangements. Journal of Applied Communication Research, 38(1), 85-105. https://doi.org/10.1080/00909880903483599

Liu, W., Zhu, R., \& Yang, Y. (2010). I warn you because I like you: Voice behavior, employee identifications, and transformational leadership. The Leadership Quarterly, 21(1), 189-202. https://doi.org/10.1016/j.leaqua.2009.10.014

Livingstone, S. (2005). In defence of privacy: Mediating the public/private boundary at home. In S. Livingstone (Ed.), Audiences And Publics: When Cultural 
Engagement Matters For The Public Sphere, Changing Media, Changing Europe (Vol. 2, pp. 163-186). Intellect Books.

Livingstone, S., \& Bober, M. (2003). UK children go online: Listening to young people's experiences [online]. LSE Research Online. http://eprints.lse.ac.uk/archive/0000388

Lojeski, K. S., \& Reilly, R. R. (2010). Leading the virtual workforce: How great leaders transform organizations in the 21st century. John Wiley \& Sons, Inc.

Lucas Jr, H. C., \& Olson, M. (1994). The impact of information technology on organizational flexibility. Journal of Organizational Computing, 4(2), 155-176. https://doi.org/10.1080/10919399409540221

Luo, Y., Jiang, H., \& Kulemeka, O. (2015). Strategic Social Media Management and Public Relations Leadership: Insights from Industry Leaders. International Journal of Strategic Communication, 9(3), 167-196. https://doi.org/10.1080/1553118X.2014.960083

Lupton, D. (2013). The Digitally Engaged Patient: Self-Monitoring and Self-Care in the Digital Health Era. Social Theory \& Health, 11(3), 256-270. https://doi.org/10.1057/sth.2013.10

MacKenzie, D. A., \& Wajcman, J. (Eds.). (1999). The Social Shaping of Technology (2nd ed.). Open University Press.

Mansfield, J. (2010). The Nature of Change Or the Law of Unintended Consequences. Imperial College Press.

Marshall, J. P. (2006, September 27). Information Technology, Disruption and Disorder: Australian Customs and IT. Seventh Association of Internet Researchers Conference. Association of Internet Researchers Annual Conference, Brisbane. 
McAfee, A. P. (2006). Enterprise 2.0: The Dawn of Emergent Collaboration. MIT Sloan Management Review, 47(3), 21-28.

Mesmer-Magnus, J., DeChurch, L., Jimenez-Rodriguez, M., Wildman, J., \& Shuffler, M. (2011). A meta-analytic investigation of virtuality and information sharing in teams. Organizational Behavior and Human Decision Processes, 115(2), 214 225. https://doi.org/10.1016/j.obhdp.2011.03.002

Meyer, C., \& Kirby, J. (2010). Leadership in the Age of Transparency. Harvard Business Review, 88(4), 38-46.

Milliken, E. W., Morrison, E. W., \& Hewlin, P. F. (2003). An exploratory study of employee silence: Issues that employees don't communicate upward and why. Journal of Management Studies, 40(6), 1453-1476. https://doi.org/10.1111/1467-6486.00387

Mohammad, K. (2009). E-Leadership: The Emerging New Leadership for the Virtual Organization. Journal of Managerial Sciences, 3(1), 1-21.

Newcombe, T. (2009). From Obscurity to OVERDRIVE. Public CIO, 7(5), 12-17.

Newman, R., Chang, V., Walters, R. J., \& Wills, G. B. (2016). Web 2.0-The past and the future. International Journal of Information Management, 36(4), 591-598. https://doi.org/10.1016/j.ijinfomgt.2016.03.010

Ng, E. S. W., Schweitzer, L., \& Lyons, S. T. (2010). New generation, great expectations: A field study of the millennial generation. Journal of Business and Psychology, 25(2), 281-292. https://doi.org/10.1007/s10869-010-9159-4

Nimmo, R. (2011). Actor-Network Theory and Methodology: Social Research in a More-Than-Human World. Methodological Innovations Online, 6(3), 108-119. https://doi.org/10.4256/mio.2011.010 
Norman, S., Avolio, B., \& Luthans, F. (2010). The impact of positivity and transparency on trust in leaders and their perceived effectiveness. Leadership Quarterly, 21(3), 350-364. https://doi.org/10.1016/j.leaqua.2010.03.002

Okhuysen, G. A., Lepak, D., Ashcraft, K. L., Labianca, G. (Joe), Smith, V., \& Steensma, H. K. (2013). Theories of Work and Working Today. Academy of Management Review, 38(4), 491-502. https://doi.org/10.5465/amr.2013.0169

Oliveira, J., \& Clegg, S. (2015). Paradoxical puzzles of control and circuits of power. Qualitative Research in Accounting \& Management, 12(4), 425-451. https://doi.org/10.1108/QRAM-02-2015-0023

O’Reilly, T. (2007). What Is Web 2.0: Design Patterns and Business Models for the Next Generation of Software. Communications And Strategies, 65(1), 17-37.

Orlikowski, W. J., \& Scott, S. V. (2008). The Entanglement of Technology and Work In Organizations. Information Systems and Innovation Group, Department of Management, LSE, Working Paper Series, No 168. http://eprints.1se.ac.uk/33898/1/wp168.pdf

Pellegrini, E. K., \& Scandura, T. A. (2008). Paternalistic Leadership: A Review and Agenda for Future Research. Journal of Management, 34(3), 566-593. https://doi.org/10.1177/0149206308316063

Pinch, T. J., \& Bijker, W. E. (1989). The Social Construction of Facts and Artifacts: Or How the Sociology of Science and The Sociology of Technology Might Benefit Each Other. In W. E. Bijker, T. P. Hughes, \& T. Pinch (Eds.), The Social Construction of Technological Systems: New Directions In The Sociology and History of Technology (pp. 17-50). MIT Press.

Randel, A. E., \& Ranft, A. L. (2007). Motivations to Maintain Social Ties With Coworkers: The Moderating Role of Turnover Intentions on Information 
Exchange. Group \& Organization Management, 32(2), 208-232. https://doi.org/10.1177/1059601106286778

Reyt, J.-N., \& Wiesenfeld, B. M. (2015). Seeing the Forest for the Trees: Exploratory Learning, Mobile Technology, and Knowledge Workers’ Role Integration Behaviors. Academy of Management Journal, 58(3), 739-762. https://doi.org/10.5465/amj.2013.0991

Rudman, R., \& Bruwer, R. (2016). Defining Web 3.0: Opportunities and challenges. The Electronic Library, 34(1), 132-154. Emerald Insight. https://doi.org/10.1108/EL-08-2014-0140

Schatzki, T. R., Cetina, K. K., \& Savigny, E. von (Eds.). (2001). The Practice Turn in Contemporary Theory. Routledge. https://doi.org/10.4324/9780203977453

Shamir, B. (1999). Leadership in Boundaryless Organizations: Disposable or Indispensable? European Journal of Work and Organizational Psychology, 8(1), 49-71. https://doi.org/10.1080/135943299398438

Shamir, B., \& Ben-Ari, E. (1999). Leadership in an open army? Civilian connections, interorganizational frameworks, and changes in military leadership. In G. J. Hunt, G. E. Dodge, \& L. Wong (Eds.), Out-of-the-box leadership: Transforming the twenty-first century army and other top-performing organizations (pp. 1540). JAI Press.

Shapin, S. (1998). Placing the View from Nowhere: Historical and Sociological Problems in the Location of Science. Transactions of the Institute of British Geographers, 23(1), 5-12. https://doi.org/10.1111/j.0020-2754.1998.00005.x

Simanowski, R. (Ed.). (2016). Digital humanities and digital media: Conversations on politics, culture, aesthetics, and literacy. Open Humanities Press. 
Smith, M. R., \& Marx, L. (1994). Does Technology Drive History? : The Dilemma of Technological Determinism (M. R. Smith \& L. Marx, Eds.). MIT Press.

Smith, M. R., \& Marx, L. (1998). Technological Determinism in American Culture. In Does Technology Drive History? The Dilemma of Technological Determinism (pp. 1-36). MIT Press.

Smola, K. W., \& Sutton, C. D. (2002). Generational differences: Revisiting generational work values for the new millennium. Journal of Organizational Behavior, 23(4), 363-382. https://doi.org/10.1002/job.147

Spector, P. (2014). Introduction: The Problems and Promise of Contemporary Leadership Theories. Journal of Organizational Behavior, Wiley Online Library(Early View). https://doi.org/10.1002/job.1930

Stanton, A., \& Stanton, W. (2013). Digital Natives Or Digital Neophytes: Business Student Perspectives On Course-Based Web 2.0 Applications. Academy Of Educational Leadership Journal, 17(1), 119-137.

Stanton, J. M., \& Barnes-Farrell, J. L. (1996). Effects of electronic performance monitoring on personal control, task satisfaction and task performance. The Journal of Applied Psychology, 81(6), 738-745. https://doi.org/10.1037/00219010.81 .6 .738

Subašić, E., Reynolds, K. J., Turner, J. C., Veenstra, K. E., \& Haslam, S. A. (2011). Leadership, power and the use of surveillance: Implications of shared social identity for leaders' capacity to influence. The Leadership Quarterly, 22(1), 170-181. https://doi.org/10.1016/j.leaqua.2010.12.014

Takaragawa, S., \& Carty, V. (2012). The 2008 U.S. Presidential Election and New Digital Technologies: Political Campaigns as Social Movements and the 
Significance of Collective Identity. Tamara Journal For Critical Organization Inquiry, 10(4), 73-89.

Tett, G. (2015). The Silo Effect: The Peril of Expertise and the Promise of Breaking Down Barriers. Simon \& Schuster.

Tredgold, P. G. (2014). Are you connected? Leadership in the era of social media. Development and Learning in Organizations: An International Journal, 28(6), 9-11. https://doi.org/10.1108/dlo-05-2014-0032

Turkle, S. (2005). The Second Self: Computers And The Human Spirit (20th Anniversary). MIT Press.

Turkle, S. (2011). Alone Together: Why We Expect More from Technology and Less from Each Other. Basic Books.

Tushman, M. L., \& Murmann, J. P. (2003). Dominant designs, technology cycles, and organizational outcomes. In R. Garud, A. Kumaraswamy, \& R. N. Langlois (Eds.), Managing in the Modular Age: Architectures, Networks, and Organizations (pp. 316-347). Blackwell Publishers Ltd.

Uhl-Bien, M. (2006). Relational Leadership Theory: Exploring the social processes of leadership and organizing. The Leadership Quarterly, 17(6), 654-676. https://doi.org/10.1016/j.leaqua.2006.10.007

Valcour, P. M., \& Hunter, L. W. (2005). Technology, Organizations and Work-life Integration. In E. E. Kossek \& S. J. Lambert (Eds.), Work and Life Integration: Organizational, Cultural, and Individual Perspectives (pp. 61-84). Lawrence Erlbaum.

van House, A. N. (2004). Science and Technology Studies and Information Studies. Annual Review of Information Science and Technology, 38(1), 3-86. https://doi.org/10.1002/aris. 1440380102 
Venters, J. W., Green, M. T., \& Lopez, D. M. (2012). Social Media: A Leadership Challenge. Business Studies Journal, 4(Special Issue 1), 85-93.

Vodanovich, S., Sundaram, D., \& Myers, M. (2010). Digital Natives and Ubiquitous Information Systems. Information Systems Research, 21(4), 711-723. https://doi.org/10.1287/isre.1100.0324

Warner, J., \& Sandberg, A. (2010). Generational leadership (pp. 1-12). ReadyToManage Inc.

Weick, K. E., Sutcliffe, K. M., \& Obstfeld, D. (2005). Organizing and the Process of Sensemaking. Organization Science, 16(4), 409-421. https://doi.org/10.1287/orsc.1050.0133

West, J. P., \& Bowman, J. S. (2016). Electronic Surveillance at Work. Administration \& Society, 48(5), 628-651. https://doi.org/10.1177/0095399714556502

Westin, A. F. (1992). Two key factors that belong in a macroergonomic analysis of electronic monitoring: Employee perceptions of fairness and the climate of organizational trust or distrust. Applied Ergonomics, 23(1), 35-42. https://doi.org/10.1016/0003-6870(92)90008-J

Westwood, R. (1997). Harmony and patriarchy: The cultural basis for paternalistic headship among the overseas Chinese. Organization Studies, 18(3), 445-480. https://doi.org/10.1177/017084069701800305

Woodward, J. (1965). Industrial organization: Theory and Practice. Oxford University Press.

Woolgar, S. (1991). The Turn to Technology in Social Studies of Science. Science, Technology, \& Human Values, 16(1), 20-50. https://doi.org/10.1177/016224399101600102 
Wyatt, S. (2008). Technological Determinism Is Dead; Long Live Technological Determinism. In E. J. Hackett, O. Amsterdamska, M. Lynch, \& J. Wajcman (Eds.), The Handbook of Science and Technology (3rd ed., pp. 165-180). MIT Press.

Zuboff, S. (1988). In The Age of The Smart Machine: The Future of Work and Power. Basic Books Inc., NY.

Zuboff, S. (1996). The Emperor's New Information Economy. In W. J. Orlikowski, G. Walsham, M. R. Jones, \& J. I. DeGross (Eds.), Information Technology and Changes in Organizational Work (pp. 13-17). Chapman and Hall. 
Table 1: Table of technologically induced relational paradox stemming from the technologized team relationship.

\begin{tabular}{|c|c|c|}
\hline $\begin{array}{l}\text { Intended outcomes for } \\
\text { technologized team } \\
\text { relationships }\end{array}$ & Propositions & $\begin{array}{l}\text { Unintended } \\
\text { consequences }\end{array}$ \\
\hline $\begin{array}{l}\text { Enhanced social } \\
\text { interaction within } \\
\text { teams }\end{array}$ & $\begin{array}{l}\text { Proposition 1: Web } 2.0 \text { technologies } \\
\text { that are implemented to support team } \\
\text { interactions within organizations are } \\
\text { more likely to promote distant } \\
\text { leadership than relational forms of } \\
\text { leadership that enhance the quality of } \\
\text { the team relationship. }\end{array}$ & Social isolation \\
\hline $\begin{array}{l}\text { Increased team } \\
\text { participation }\end{array}$ & $\begin{array}{l}\text { Proposition 2: Team interactions over } \\
\text { Web } 2.0 \text { technologies silences an } \\
\text { excluded group of individuals resulting } \\
\text { in an overestimation of power by those } \\
\text { participating in the technologized team } \\
\text { relationship. }\end{array}$ & Exclusion \\
\hline $\begin{array}{l}\text { Improved information } \\
\text { access }\end{array}$ & $\begin{array}{l}\text { Proposition 3: Information sharing in a } \\
\text { technologized team relationship is } \\
\text { determined by the motivations of the } \\
\text { one sharing the information, the nature } \\
\text { of the information to be shared, and the } \\
\text { perception held about the Web } 2.0 \\
\text { technological platform on which the } \\
\text { information is shared. }\end{array}$ & $\begin{array}{l}\text { Information } \\
\text { (self-) } \\
\text { censorship }\end{array}$ \\
\hline $\begin{array}{l}\text { Team process } \\
\text { transparency }\end{array}$ & $\begin{array}{l}\text { Proposition 4: Transparency in a } \\
\text { technologized team relationship is } \\
\text { determined by the perception, nature } \\
\text { and extent of surveillance in the team. }\end{array}$ & $\begin{array}{l}\text { Team } \\
\text { surveillance }\end{array}$ \\
\hline
\end{tabular}


Figure 1: The nature of the technologized team relationship

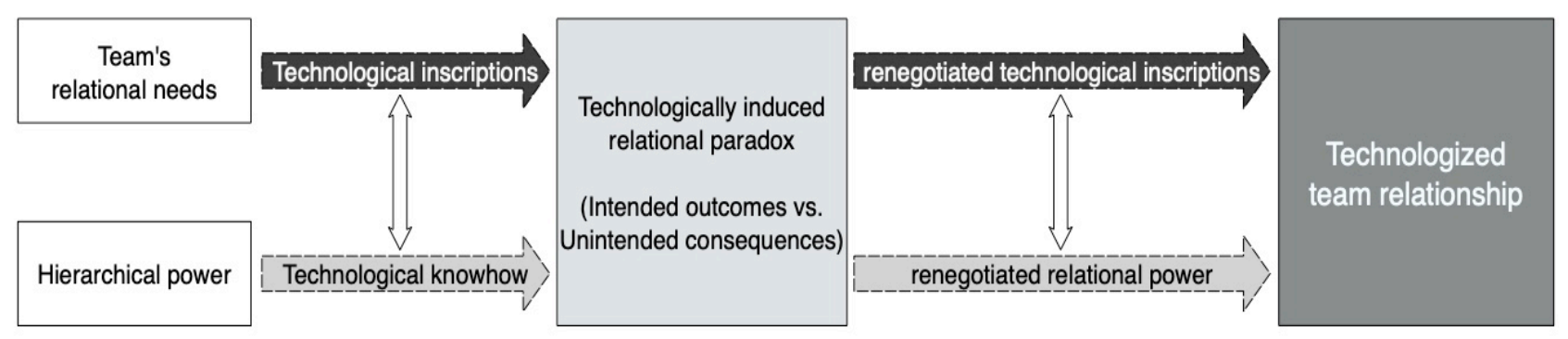

